International Journal of Trend in Scientific Research and Development (IJTSRD)

Volume: 3 | Issue: 3 | Mar-Apr 2019 Available Online: www.ijtsrd.com e-ISSN: 2456 - 6470

\title{
HIV/AIDS and the Reflection of Sexual Invisibility in the Elderly in Brazil
}

\author{
Bruna Balbina De Melo E Silva ${ }^{1}$, Clarisse Vieira De Almeida ${ }^{1}$, Elza De Araújo Dantas ${ }^{\mathbf{1}}$, \\ Henrique Eduardo Romão Arboés ${ }^{1}$, Larissa Queiroz De Oliveira ${ }^{1}$, \\ Amália Cinthia Meneses Rêgo², Francisco Irochima Pinheiro², Irami Araújo-Filho²
}

\begin{abstract}
${ }_{1}^{1}$ Student of Scientific Initiation and Graduation in Medicine of Potiguar University - UnP - Natal / Brazil
${ }^{2}$ Full Professor of the PG Program in Biotechnology, Potiguar University (UnP), Natal, Rio Grande do Norte, Brazil ${ }^{2} \mathrm{Ph} . \mathrm{D}$. in Health Science, Laureate International Universities, Natal, Rio Grande do Norte, Brazil
\end{abstract}

\begin{abstract}
How to cite this paper: Bruna Balbina De Melo E Silva | Clarisse Vieira De Almeida | Elza De Araújo Dantas | Henrique Eduardo Romão Arboés | Larissa Queiroz De Oliveira | Amália Cinthia Meneses Rêgo | Francisco Irochima Pinheiro | Irami Araújo-Filho "HIV/AIDS and the Reflection of Sexual Invisibility in the Elderly in Brazil" Published in International Journal of Trend in Scientific Research and Development

(ijtsrd), ISSN: 2456-

6470, Volume-3 |

Issue-3 , April 2019, pp.890-894, URL: https://www.ijtsrd.c om/papers/ijtsrd23 041.pdf

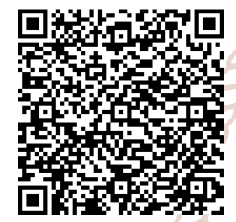

IITSRD23041
\end{abstract}

Copyright (C) 2019 by author(s) and International Journal of Trend in Scientific Research and Development Journal. This is an Open Access article distributed under the terms of the Creative Commons

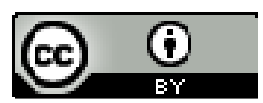
Attribution License (CC BY 4.0) (http://creativecommons.org/licenses/ by/4.0)

\section{Introduction}

The Acquired Immunodeficiency Syndrome (AIDS) is a recent disease that scared the world of its discovery and was elucidated by advances in the field of research ${ }^{1}$. Its first registration occurred in 1981 when it was observed clinically in the United States United States, in groups of patients with impaired immunity for no apparent reason who had Pneumocystis carinii pneumonia and Kaposi sarcoma pneumonia ${ }^{1-3}$, at which time the Centers for Disease Control and Prevention (CDC) became aware of the outbreak and investigations ${ }^{4}$.

Initially, the CDC called the disease "4H's disease" because they perceived an initial relationship with Haitian patients, homosexuals, hemophiliacs, and heroin users 5 . In the press, the term "Gay-Related Immune Deficiency" (GRID) was added, which translated into Portuguese would be "Immune Deficiency related to gays." It was only when it was perceived that the disease could affect several groups; the term AIDS was created in 1982, which has spread to the present day ${ }^{5,6}$.

In 1983, Robert Gallo and Luc Montagnier, researchers from different groups, simultaneously declared the discovery of a new retrovirus, which would be associated with patients affected by AIDS and announced to the world the possible etiology of that syndrome, the virus that would later be known as Human Immunodeficiency Virus (HIV) ${ }^{7}$. With the discovery of the new disease, a need arose for treatment for its control. That was when, in 1987, Zidovudine (AZT), the first antiretroviral drug to revolutionize the history of HIV/AIDS, was approved for use in virus control through a placebo test. Subsequently, the Brazilian Ministry of Health established the National Sexually Transmitted Diseases STDs/AIDS Program ${ }^{8,9}$. 
Over the following decades, new technologies, drugs and advances in research have emerged, causing Brazil to persist in the fight against the virus, with the production and distribution of barrier contraceptives and antiretrovirals (ARVs), as well as through the implementation of a public network of laboratories, services and research funding indicating a promising future with regard to syndromic control and viral load reduction ${ }^{9}$.

Some concepts and opinions have been constructed in the course of the long history of the HIV/AIDS epidemic, initially believed to be a disease restricted to homosexuals, drug users and sex workers. Over the years, the concepts have changed, with the spread of the virus in several population profiles, including the elderly ${ }^{10}$. The Brazilian Elderly Statute defines "elderly people" as those aged 60 or over ${ }^{11}$.

In Brazil, from 1980 to June 2017, there were 576,245 cases of AIDS in men and 306,444 in women, corresponding to the occurrence of $65.3 \%$ of cases in males and $34.7 \%$ in females. When comparing the years 2006 and 2016, there is an increase in the prevalence of AIDS in men and women aged 60 years or more ${ }^{12}$.

Godoy et al., in an epidemiological study conducted in consultation with the Department of Informatics of the Brazilian Unified Health System (DATASUS), demonstrated that in the period from 1995-2005, 7,955 new AIDS cases were diagnosed in individuals aged $\geq 60$ years, is $51.66 \%$ due to heterosexual intercourse ${ }^{13}$. Cerqueira and Rodrigues interviewed 20 elderly people living with HIV/AIDS in Belo Horizonte/MG /Brazil and reported that $90 \%$ of these had predominantly low levels of education associated / with poverty ${ }^{14}$.

Santos and Assis affirm that the possible factors related to the vulnerability of the elderly in the face of the HIV/AIDS epidemic are the invisibility of sexuality in old age, the greater participation of the elderly in old age groups, the emergence of drugs that stimulate sexual performance, the use of male condoms and the need for more powerful prevention policies in the geriatric population ${ }^{15}$.

Even though population aging and the vulnerability of older people to sexually transmitted infections are evident, the present study, which proposes a more in-depth comparative assessment of the growth rates of reported cases of HIV/AIDS, as well as AIDS in the different age groups of the Brazilian population, with emphasis on the group of geriatric patients ${ }^{16}$.

\section{Methods}

A descriptive epidemiological study was carried out with data obtained through consultation of the databases of the Notification of Injury Information System (SINAN), the System for the Control of Laboratory Tests of the National Network of CD4+/CD8+ Lymphocyte Count and Viral Load (SISCEL), the Logistic Control System for Medicines (SICLOM) and the Mortality Information System (MIS). These data were used as sources for the 2017 HIV/AIDS Epidemiological Bulletin of the Department of Surveillance, Prevention and Control of Sexually Transmitted Infections, HIV/AIDS and Viral Hepatitis, Ministry of Health Ministry of Health (DIAHV/SVS/MS), available at the electronic address (http://www.aids.gov.br), accessed between 10/10/2018 and $10 / 24 / 2018$.
The study population consisted of all reported HIV cases from 2007-2016, as well as cases of AIDS and AIDS deaths reported from 1980-2016 in people aged 20 years or older. It is essential to affirm that a significant sample was used to represent the prevalence/incidence of HIV and AIDS in different age groups during the period analyzed in the study to enrich the research as a safe source of epidemiological data enabling the scientific validity of the results, discussion, and conclusion. Data were reported that were not included in the individuals' age or were younger than 20 years. To avoid selection biases, data for the year 2017 were excluded and, although available in the Epidemiological Bulletin, were incomplete (notifications made 06/30/2017).

In the present study, the population under analysis was divided into nine subgroups, similarly to the HIV/AIDS Epidemiological Bulletin, and their male and female equivalents, as follows: $20-24 ; 25-29$; 30-34; 35-39; 40-44; 45-49; 50-54; 55-59; 60 years or more. This last subgroup corresponds to the elderly patients ${ }^{11}$. Through this division, statistics on the growth of HIV, AIDS, and death by AIDS in each age group-subgroup were analyzed, and evaluation tables were elaborated.

Because the database is in the public domain, there was no need to submit the study to the Research Ethics Committee of Potiguar University/UnP/Natal/Brazil.

\section{Results}

In the analysis of the number of HIV cases reported according to sex and age group in the period 2007-2016 (Table 1), corresponding to 10 years, there was a peak of notification in both the male and female sexes in the 20-24, 25-29 and 30-34 years. From the age of 35, there was a progressive decrease in the number of diagnoses, being significantly lower in the elderly. In all reports, individuals aged 20-34 years accounted for approximately $56.65 \%$ of the cases, with the elderly being represented by only $3.13 \%$ of the total number.

Table1. Cases of HIVa (number and percentage) notified in the SINAN ${ }^{b}$ according to gender and age. Brazil, 2007-

\begin{tabular}{|c|c|c|c|}
\hline Age group & Male & Female & Total \\
\hline Years & $\mathbf{n}$ & $\mathbf{n}$ & $\mathbf{N}(\%)$ \\
\hline $20-24$ & 22,902 & 7,830 & $30,732(18.68 \%)$ \\
\hline $25-29$ & 24,345 & 9,225 & $33,570(20.40 \%)$ \\
\hline $30-34$ & 19,882 & 9,033 & $28,915(17.57 \%)$ \\
\hline $35-39$ & 14,837 & 7,659 & $22,496(13.67 \%)$ \\
\hline $40-44$ & 10,816 & 6,051 & $16,867(10.25 \%)$ \\
\hline $45-49$ & 8,141 & 4,724 & $12,865(7.82 \%)$ \\
\hline $50-54$ & 5,207 & 3,521 & $8,728(5.30 \%)$ \\
\hline $55-59$ & 3,009 & 2,195 & $5,204(3.16 \%)$ \\
\hline$\geq 60$ & 3,090 & 2,068 & $5,158(3.13 \%)$ \\
\hline Total & 112,229 & 52,306 & 164.53500 \\
\hline
\end{tabular}

aHIV(Human Immunodeficiency Virus); bSINAN (Information System of Notifiable Diseases). Source: MS/SVS/Department of Surveillance, prevention and control of STIs, HIV/AIDS and Viral Hepatitis. Available in http://www.aids.gov.br. Accessed on 24/10/2018. Table adapted by the authors, according to the objective of the research.

About the number of AIDS cases reported according to sex and age group in the periods 1980-2004 (24 years) and 
2005-2016 (12 years) (Table 2). We noticed an increase of $16.27 \%$ (from $251,273-292,160$ ) in the whole male sex, reaching a $109.12 \%$ increase (from 6,039-12,629) in elderly men, that is, the number of reported cases of AIDS in this group doubled in a period that corresponds to half the time initially analyzed. In females, comparing this same period, there was an increase of $47.10 \%$ (from $113,669-167,214$ ) in the total value, reaching $208.44 \%$ (from $2,665-8,220$ ) in senior women, which corresponds to three times reported cases in a period equivalent to half the time initially studied.

Table 2. Cases of AIDS ${ }^{a}$ notified in the SINAN , declared in the MISc and registered in the SISCEL ${ }^{\mathrm{d}} /$ SICLOM $^{\mathrm{e}}$ According to gender, age group (age in years) and notification sub-periods. Brazil, 1980-2016.

\begin{tabular}{|c|c|c|c|c|c|c|}
\hline \multicolumn{7}{|c|}{ Male } \\
\hline Age (years) & $\begin{array}{c}1980-2004 \\
(\mathbf{n})\end{array}$ & $\begin{array}{c}\mathbf{2 0 0 5 - 2 0 1 6} \\
(\mathbf{n})\end{array}$ & $\begin{array}{c}\mathbf{2 0 0 7 - 2 0 1 6} \\
(\mathbf{n})\end{array}$ & $\begin{array}{c}\mathbf{1 9 8 0 - 2 0 0 4} \\
(\mathbf{n})\end{array}$ & $\begin{array}{c}\mathbf{2 0 0 5 - 2 0 1 6} \\
(\mathbf{n})\end{array}$ & $\begin{array}{c}\mathbf{2 0 0 7 - 2 0 1 6} \\
(\mathbf{n})\end{array}$ \\
\hline $20-24$ & 22,313 & 25,767 & 22,919 & 15,104 & 14,230 & 11,645 \\
\hline $25-29$ & 47,337 & 45,074 & 38,914 & 24,017 & 24,327 & 19,487 \\
\hline $30-34$ & 57,664 & 52,162 & 44,213 & 24,070 & 29,297 & 23,773 \\
\hline $35-39$ & 48,410 & 48,916 & 40,616 & 18,948 & 27,715 & 22,776 \\
\hline $40-44$ & 32,914 & 42,005 & 34,923 & 13,104 & 23,889 & 19,770 \\
\hline $45-49$ & 19,653 & 31,881 & 27,223 & 8,197 & 18,519 & 15,726 \\
\hline $50-54$ & 10,961 & 21,191 & 18,375 & 4,855 & 12,933 & 11,142 \\
\hline $55-59$ & 5,982 & 12,535 & 10,955 & 2,709 & 8,084 & 7,123 \\
\hline$\geq 60$ & 6,039 & 12,629 & 11,178 & 2,665 & 8,220 & 7,282 \\
\hline Total & 251,273 & 292,160 & 249,316 & 113,669 & 167,214 & 138,724 \\
\hline
\end{tabular}

aAIDS (Acquired Immunodeficiency Syndrome); bSINAN (Information System of Notifiable Diseases); cMIS (Mortality Information System); dSISCEL (Control System of Laboratory Tests of the National network of CD4 lymphocyte count +/CD8 + and HIV Viral load); eSICLOM (Logistic Control System of Medicines). Source: MS/SVS/Department of Surveillance, prevention and control of STIs, HIV/AIDS and viral hepatitis. Available in http://www.aids.gov.br. Accessed on 24/10/2018. Table adapted by the authors, according to the objective of the research.

Comparing information on the number of AIDS cases reported in the period 2007-2016 (Table 2) and the number of HIV cases reported in the same period (Table 1), there was a progressive increase in the number of cases with the advancement of the age group. In the male sex, the AIDS/HIV ratio evolves as follows: young people aged 20-24 years presented a 1:1 ratio; $25-29$ years $-1.59: 1 ; 30-34$ years - $2.22: 1 ; 35-39$ years $-2.73: 1 ; 40$ - 44 years - $3.22: 1 ; 45-49$ years - $3.34: 1 ; 50-54$ years- $3.52: 1 ; 55-59$ years 3.64: $1 ; 60$ years or more ratio 3.61:1. In the female sex, the AIDS/HIV relationship followed a similar trend: young people aged 20-24 years presented a 1.48:1 ratio; $25-29$ years - $2.11: 1 ; 30-34$ years - $2.63: 1 ; 35-39$ years $-2.97: 1 ; 40$ - 44 years - $3.26: 1 ; 45$ 49 years $-3.32: 1 ; 50-54$ years $-3.16: 1 ; 55-59$ years $-3.24: 1 ; 60$ years or more ratio 3.52:1.

Analyzing the number of deaths due to AIDS according to sex and age range (Table 3) from 1980-2004 (24 years) and 20052016 (12 years), we observed a constant drop in males between the ages of 20 and 44 , with an increase of $27.30 \%$ (from $10,624-13,525)$ in the $45-49$ age group, $57.04 \%(5,967-9,371)$ from 50 to 54 years, $78,53 \%(3,397-6,065)$ of the $55-59$ years and $89.45 \%(3,869-7,330)$ in the elderly. Similarly, in females, we had a decrease in the 20-34 age group, with a progressive increase in the number of deaths: from $20.55 \%(7,077-8,532)$ from $35-39$ years; $53.38 \%(5,199-7,852)$ between the ages of 40 and $44 ; 91.14 \%$ (3.342-6.388) from $45-49$ years; $123.37 \%$ (1942-4.338) from $50-54$ years; $137.25 \%(1,181-2,802)$ from $55-59$ years and $161.96 \%(1,404-3,678)$ in individuals aged 60 years and over.

Table3. Number of deaths from AIDS according to gender, age and notification subperiods Brazil, 1980-2016

\begin{tabular}{|c|c|c|c|c|}
\hline \multicolumn{3}{|c|}{ Male } & \multicolumn{2}{c|}{ Female } \\
\hline Age (Years) & $\mathbf{1 9 8 0 - 2 0 0 4}(\mathbf{n})$ & $\mathbf{2 0 0 5 - 2 0 1 6}(\mathbf{n})$ & $\mathbf{1 9 8 0 - 2 0 0 4}(\mathbf{n})$ & $\mathbf{2 0 0 5 - 2 0 1 6}(\mathbf{n})$ \\
\hline $20-24$ & 8,674 & 3,334 & 3,942 & 1,965 \\
\hline $25-29$ & 21,787 & 8,629 & 7,832 & 4,664 \\
\hline $30-34$ & 28,129 & 13,315 & 8,569 & 7,264 \\
\hline $35-39$ & 24,566 & 15,848 & 7,077 & 8,532 \\
\hline $40-44$ & 17,289 & 16,013 & 5,119 & 7,852 \\
\hline $45-49$ & 10,624 & 13,525 & 3,342 & 6,388 \\
\hline $50-54$ & 5,967 & 9,371 & 1,942 & 4,338 \\
\hline $55-59$ & 3,397 & 6,065 & 1,181 & 2,802 \\
\hline$\geq 60$ & 3,869 & 7,330 & 1,404 & 3,678 \\
\hline Total & 124,302 & 93,430 & 40,408 & 47,483 \\
\hline
\end{tabular}

AIDS (Acquired Immunodeficiency Syndrom). Source: MS/SVS/DANTPS/Mortality Information System (MIS). Available in http://www.aids.gov.br. Accessed 10/24/2018 in. Table adapted by the authors, according to the objective of the research.

\section{Discussion}

The findings show that, although the elderly population corresponds to the lowest percentage of total HIV reports, there was an increase in the number of AIDS cases in this population, justifying the higher AIDS/HIV ratio in the elderly population. Also, although the absolute number of AIDS deaths in the elderly is lower than the young people in the periods 1980-2004 and 2005-2016, there has been a percentage increase over the years. 
Mesenburg et al. a study carried out with 1,222 women showed that $66.1 \%$ had already undergone HIV testing, $52.4 \%$ of which were requested by health professionals, with a higher prevalence for women prenatal aged 30-39 years ${ }^{17}$. In another study of 2,566 women and 2,194 men who had had sex, Barros found that, in line with the findings of Mesenburg et al. ${ }^{17}$, most women tested on a professional basis, while the majority of men prevalence of the age of 2635 years, performed spontaneously.

Given these data, it is noticed that most anti-HIV tests are performed by young individuals of both sexes, either by professional request or by the natural desire of the patient, which contributes to the peak of notifications in the 20-34 years, as presented in the results. This early diagnosis, unfortunately, does not occur in elderly patients, which, as already shown, corresponds to only $3.13 \%$ of the total cases reported $^{18}$.

Faced with this, this percentage may be underestimated, not reflecting the actual number of cases registered in the geriatric age group. According to Cassétte et al., This scenario may have a multi factorial cause, ranging from the socio-cultural values of elderly patients, who experienced intense prejudice and lack of acceptance of HIV in their adult lives, to poor geriatric care health, neglecting early diagnosis ${ }^{19}$. This is a reflection of the sexual invisibility of the elderly during care in the health services and the fear that professionals have to address on the subject with this population ${ }^{20}$.

The exacerbated increase in the number of AIDS cases in the elderly, doubling in men and tripling in women in a period corresponding to half of the initial one, reflects the underestimation of the personal risk of contagion and beliefs about the pathology, aspects that increase the vulnerability of this group to disease $\mathrm{e}^{21}$. This is reaffirmed by Costa et al., Who, in an interview with 78 senior women, found limitations in the knowledge about AIDS in $65.3 \%$ of the group 22 .

Because AIDS is the most advanced clinical manifestation due to the immunodeficiency caused by HIV, both vulnerability and late diagnosis can be expressed again by the high AIDS/HIV ratio in the population over 60 years old. As shown in the results, in the same period, regardless of gender, the number of reported AIDS cases was predominantly higher than the number of HIV cases, especially in the elderly, a subgroup that presented the highest AIDS/HIV ratio in both sexes ${ }^{16-18,23}$

Melo et al., Identified that young adults think differently from the elderly with a similar level of education, about knowledge of the disease, preventive behaviors, and importance of the HIV test ${ }^{24}$. Many elderly people do not know how to use condoms and /or do not practice this practice as a habit, because of their familiarity with the sexual partner, assuming that it is not contaminated, or, in the case of women, by the use of the consent of the man, the most susceptible to attitudes of risk ${ }^{25,26}$.

This personal factor associated with the health professionals' view of "asexuality in the elderly" has contributed to the discovery of HIV infection in the advanced form of immunosuppression ${ }^{26}$.
Regarding adherence to antiretroviral therapy (ART), it is known that several issues are involved, from the acceptance of the diagnosis to the false belief, still present in the imaginary of the population, especially in the elderly, that the disease does not exist and/or does not cause health problems ${ }^{14}$. Also, associated cadres of lack of social support, polypharmacy and mental disorders (depression and anxiety), often prevalent in the geriatric population, further hamper adherence to the treatment of chronic diseases, reinforcing the increase in the AIDS/HIV relationship ${ }^{27,28}$.

This greater difficulty in therapeutic adherence ends up converging to data referring to AIDS deaths. Although the absolute number in the elderly is lower when compared to the younger age groups, the increase of $89.45 \%$ in male deaths and $161.96 \%$ in females in a period corresponding to half of the previously analyzed allows raising two hypotheses: the success of the National Anti-AIDS Program implemented in Brazil in the 1990s, which made it possible to increase the life expectancy of the population that acquired the disease 20-30 years ago, thus resulting in the percentage growth of death rates in the elderly ${ }^{29}$; the second hypothesis would be the failure to perform early diagnosis in this group, as a consequence of the still existing taboo on the sexuality of the elderly ${ }^{20}$, as well as the various factors that contribute to no adherence to ART, leaving the geriatric population more susceptible to AIDS14,27,28.

\section{Conclusion}

In conclusion, the present study presupposes the need for effective strategies that provide a reduction in the incidence of the disease as well as the expansion of investments in prevention, an active search involving the actions of multidisciplinary health teams in the care of elderly patients affected, including with the fundamental participation of managers in public health.

It is therefore essential to know the epidemiological bases, which, through studies based on data in the public domain, provide, in a fast and secure way, relevant information for the development of government policies aimed at halting the spread of HIV/AIDS in the oldest part of the Brazilian population.

\section{Declaration of conflict of interest}

The authors have no conflicts of interest to be declared.

\section{References}

[1] Reitz MS, Gallo RC. Human Immunodeficiency Viruses. In: Mandell GL, Bennett JE, Dolin R. Principles and practice of infectious diseases. 7th ed. Philadelphia: Elsevier; 2010. p. 2323-2336.

[2] Friedman-Kien AE. Disseminated Kaposi's sarcoma syndrome in young homosexual men. J. Am. Acad. Dermatol. 1981 Out; 5 (4): 468-471.

[3] Gottlieb MS. Pneumocystis pneumonia-Los Angeles. 1981. Am J Public Health. 2006 Jun; 96 (6): 980-981.

[4] Basavapathruni A, Anderson KS. Reverse transcription of the HIV-1 pandemic. FASEB J. 2017 Jul; 21 (14): 3795-3808.

[5] Cohen J. HIV/AIDS: Latin America \& Caribbean. HAITI: making headway under hellacious circumstances. Science. 2006 Jul 28; 313(5786):470-473. 
[6] Galvão J. 1980-2001: uma cronologia da epidemia de HIV/AIDS no Brasil e no mundo. Rio de Janeiro: ABIA; 2002.

[7] RC Gallo, PS Sarin, EP Gelmann, M Robert-Guroff, E Richardson, VS Kalyanaraman, et al. Isolation of human T-cell leukemia virus in acquired immune deficiency syndrome (AIDS). Science. 1983 May 20; 220(4599):865-867.

[8] Fischl MA, Richman DD, Grieco MH, Gottlieb MS, Volberding PA, Laskin OL, et al. The efficacy of azidothymidine (AZT) in the treatment of patients with aids and aids-related complex. A double- blind, placebo-controlled trial. N Engl J Med. 1987 Jul 23; 317(4):185-191.

[9] Greco DB. Trinta anos de enfrentamento à epidemia da Aids no Brasil, 1985-2015. Ciênc. saúde coletiva. 2016 mai; 21(5):1553-1564.

[10] Maschio MBM, Balbino AP, De Souza PFR, Kalinke LP. Sexualidade na terceira idade: medidas de prevenção para doenças sexualmente transmissíveis e aids. Rev Gaúcha Enferm 2011; 32(3):583-589.

[11] Brasil. Estatuto do idoso: Lei no 10.741, de 1 o de outubro de 2003. Dispõe sobre o Estatuto do Idoso e dá outras providências. Diário Oficial da União, Brasília (DF), 2003 out 3; Seção 1.

[12] Brasil. Ministério da saúde. Secretaria de Vigilância em Saúde. Boletim Epidemiológico - Aids e IST [Internet]. Brasília: Departamento de Vigilância, Prevenção e Controle das Infecções Sexualmente Transmissíveis, do HIV/aids e das Hepatites Virais; 2017 [citado 2018 jan. 10]. Disponível em: http://www.aids.gov.br/pt$\mathrm{br} / \mathrm{pub} / 2017 /$ boletim-epidemiologico-hivaids-2017

[13] Godoy VS, Ferreira MD, Silva EC, Gir E, Canini SRMS. 0 perfil epidemiológico da aids em idosos utilizando sistemas de informações em saúde do DATASUS: realidades e desafios. J bras Doenças Sex Transm 2008; 20(1):7-11.

[14] Cerqueira MBR, Rodrigues RN. Fatores associados à vulnerabilidade de idosos vivendo com HIV/aids em Belo Horizonte(MG), Brasil. Ciênc. saúde coletiva 2016; 21(11):3331-3338.

[15] Santos AFM, Assis M. Vulnerabilidade das idosas ao HIV/aids: despertar das políticas públicas e profissionais de saúde no contexto da atenção integral: revisão de literatura. Rev. Bras. Geriatr. Gerontol. 2011; 14(1):147-157.

[16] Andrade J, Ayres JA, Alencar RA, Duarte MTC, Parada CMGL. Vulnerabilidade de idosos a infecções sexualmente transmissíveis. Acta Paul Enferm 2017; 30(1):8-15.

[17] Mesenburg MA, Wehrmeister FC, Silveira, MF. Teste de HIV solicitado e espontâneo: um estudo de base populacional com mulheres de uma cidade do Sul do Brasil. Cad. Saúde Pública 2017; 33(10):e00074415.
[18] Barros CRS. Fatores associados à realização do teste anti-HIV na população brasileira [tese]. São Paulo (SP): Faculdade de Saúde Pública; 2012.

[19] Cassétte JB, Silva LC, Felício EEAA, Soares LA, Morais RA, Prado TS, et al. HIV/aids em idosos: estigmas, trabalho e formação em saúde. Rev. Bras. de Geriatr. e Gerontol. 2016 set-out; 19(5): 733-744.

[20] Alencar RA, Ciosak SI. O diagnóstico tardio e as vulnerabilidades dos idosos vivendo com HIV/aids. Rev Esc Enferm USP 2014; 49(2):229-235.

[21] Queiroz MAC, Lourenço RME, Coelho MMF, Miranda KCL, Barbosa GB, Bezerra STF. Representações sociais da sexualidade entre idosos. Rev Bras Enferm 2015 julago; 68(4):662-667.

[22] Costa MS, Moreira MASP, Silva AO, Leite ES, Silva LM, Sampaio JB. Saberes, crenças religiosas e atitudes de mulheres idosas na prevenção ao HIV/ais. Rev Bras Enferm [Internet] 2018 [citado 2018 jan 29]; 71(1):40$46 . \quad$ Disponível em: http://www.scielo.br/pdf/reben/v71n1/pt_00347167-reben-71-01-0040.pdf

[23] Lazzarotto AR, Deresz LF, Sprinz E. HIV/AIDS e Treinamento Concorrente: a Revisão Sistemática. Rev Bras Med Esporte 2010; 16(2):149-154.

[24] Melo HMA, Leal MCC, Marques APO, Marino JG. Awareness about aids among elderly males and Young adults: a study of the perception of this disease. Ciênc. saúde coletiva 2012;17(1):43-53.

[25] Zawacki T, Norris J, Hessler DM, Morrison DM, Stoner AS, George WH, et al. Effects of relationship motivation, partner familiarity, and alcohol on women's risky sexual decision making. Pers Soc Psychol Bull 2009 Jun; 35(6):723-736.

[26] Geluda K, Bosi MLM, Cunha AJLA, Trajman A. "It takes two to tango" a study on inconsistent use of male condoms by adolescents in Rio de Janeiro, Brazil. Cad. Saúde Pública 2006; 22(8):1671-1680.

[27] Adão VM, Caraciolo JMM. Fatores que influenciam a adesão aos antirretrovirais. In: Caraciolo JMM, Shimma E. Adesão da teoria à prática: experiências bem sucedidas no Estado de São Paulo [Internet]. São Paulo: Centro de Referência e Treinamento DST e aids; 2007 [citado 2018 jun 23]; p. 28-42.

[28] Silva AL, Ribeiro AQ, Klein CH, Acurcio FA. Utilização de medicamentos por idosos brasileiros, de acordo com a faixa etária: um inquérito postal. Cad. Saúde Pública 2012; 28(6): 1033-1045.

[29] Camargo ABM. Mortalidade por Aids entre idosos no Brasil. In: Anais do XX Encontro Nacional de Estudos Populacionais. 2016 out 17-22; Foz do Iguaçu, Brasil; 2016. 